\title{
Space Study of a Red Tide-Related Environmental Disaster near Kamchatka Peninsula in September-October 2020
}

\author{
Academician V. G. Bondur ${ }^{a}, *$, V. V. Zamshin ${ }^{a}$, and O. I. Chvertkova ${ }^{a}$ \\ Received December 16, 2020; revised December 17, 2020; accepted December 17, 2020
}

\begin{abstract}
The results of space monitoring of an extreme ecological situation near Kamchatka Peninsula, which was responsible for a mass death of hydrobionts in autumn 2020, are presented. The analysis of longterm series of satellite data ( $>15000$ scenes) on sea surface temperature (from 1981 to 2020) and concentration of chlorophyll $a$ (from 2000 to 2020) showed strong positive temperature anomalies (deviations from a climate norm $3-6^{\circ} \mathrm{C}$ ) in the studied region in July-September 2020, which resulted in anomalous increase in the concentration of chlorophyll $a$ (5-8 times higher than the background values) in the end of September-the beginning of October 2020. As a result, a significantly changed biogenic regime led to harmful bloom of algae (red tide), which caused death of hydrobionts both in Avacha Bay and coastal regions of the entire Kamchatka Peninsula.
\end{abstract}

Keywords: remote sensing, satellite monitoring, satellite data, coastal water areas, harmful bloom of algae, red tide, Kamchatka

DOI: $10.1134 / \mathrm{S} 1028334 \mathrm{X} 21030016$

\section{INTRODUCTION}

An extraordinary mass death of hydrobionts and unnatural color and odor of oceanic water were reported in September-October 2020 near Kamchatka Peninsula including Avacha Bay in the area of the Khalaktyrka beach. Several cases of intoxication of water-contacted humans were registered. Space monitoring of coastal water areas near Kamchatka Peninsula was conducted to reveal the reasons of this extraordinary ecological event.

Satellite remote sensing means have some advantages including a broad view, efficiency, possible operations in any difficult-to-access regions of seas and oceans, information with various spatial and temporal resolutions in various areas of spectrum of electromagnetic waves, a broad spectrum of registered parameters of water, and high reliability of data [1]. Using remote sensing data, one can register (i) the variations in hydrooptical characteristics of oceanic water [2], which are a result of the change in dispersion and absorption of light due to variable contents of dispersed and dissolved organic matter [3] including the presence of phytoplankton [4], (ii) distortion of spatiotemporal wave structure [1], (iii) the presence of surfactants [1], (iv) fields of currents [1], (v) internal

\footnotetext{
a AEROCOSMOS Research Institute for Aerospace Monitoring, Moscow, 105064 Russia

*e-mail: vgbondur@aerocosmos.info
}

waves [5], (vi) tidal events [6], (vii) variable sea surface temperatures (SST) [1], etc. Remote registration of these significant water parameters using results of satellite measurements [7] and results of mathematical modeling [8] allows effective monitoring of water areas, which are affected by anthropogenic $[1,9]$ and natural $[3,4]$ factors. This work provides the results of space monitoring of an extraordinary ecological situation near Kamchatka coast in autumn 2020 and related conclusions concerning its main reason.

\section{RESEARCH FEATURES AND DATA USED}

The studies were conducted in Avacha Bay (in the area of the Khalaktyrka beach), where the mass death of hydrobionts was first registered in the end of September-the beginning of October 2020, as well as in the coastal areas of the entire Kamchatka Peninsula. Satellite monitoring included collection, processing, and analysis of temporal series of current and archive remote sensing data, as well as additional information. More than 15000 archive and current satellite images of AQUA, TERRA, NOAA, SENTINEL-1/2 and other missions were collected and processed. The geoinformation technologies and integrated interfaces of data exchange allowed application of specific methods of processing of satellite images and additional information [10]. In this work, we used approaches tested during remote studies in various areas of seas and oceans $[1-3,7,9]$, as well as experience during elaboration and application of experimental sample of 
Table 1. Main studied water parameters, data sources, and tasks

\begin{tabular}{|c|c|c|c|c|}
\hline Studied parameter & Data source & Period of study & Temporal range & Main tasks \\
\hline \multirow[t]{2}{*}{$\begin{array}{l}\text { Concentration } \\
\text { of chlorophyll } a \text { in } \\
\text { the subsurface layer }\end{array}$} & $\begin{array}{l}\text { Multispectral images } \\
\text { from MODIS spec- } \\
\text { tral radiometers of } \\
\text { AQUA/TERRA mis- } \\
\text { sions }\end{array}$ & $\begin{array}{l}\text { February 24, 2000- } \\
\text { October 31, } 2020\end{array}$ & Daily & $\begin{array}{l}\text { 1. Analysis of long-term ( } ~ 20 \text { years) } \\
\text { series of the concentration of chloro- } \\
\text { phyll } a \text { (averaged by the area of Avacha } \\
\text { Bay), comparison of research results } \\
\text { of } 2020 \text { with a climate normal } \\
\text { 2. Formation and analysis of average } \\
\text { month maps of the concentration of } \\
\text { chlorophyll } a \text { for all Kamchatka coastal } \\
\text { areas }\end{array}$ \\
\hline & $\begin{array}{l}\text { Multispectral images } \\
\text { from VIIRS scan- } \\
\text { ning radiometers of } \\
\text { NOAA missions }\end{array}$ & $\begin{array}{l}\text { January 1, 2019- } \\
\text { October 10, 2020 }\end{array}$ & Daily & $\begin{array}{l}\text { 1. Analysis of spatial distribution of the } \\
\text { concentration of chlorophyll } a \text { in the } \\
\text { Avacha Bay during the environmental } \\
\text { disaster }\end{array}$ \\
\hline \multirow[b]{2}{*}{ SST } & $\begin{array}{l}\text { Data of MODIS } \\
\text { spectral radiometers } \\
\text { of AQUA/TERRA } \\
\text { missions }\end{array}$ & $\begin{array}{l}\text { June } 1,2020- \\
\text { October } 10,2020\end{array}$ & Daily & $\begin{array}{l}\text { 1. Analysis of spatial SST distribution } \\
\text { in the Avacha Bay during summer } 2020 \\
\text { and during the ecological disaster }\end{array}$ \\
\hline & $\begin{array}{l}\text { Optimal interpola- } \\
\text { tion SST (OISST) } \\
\text { NOAA }\end{array}$ & $\begin{array}{l}\text { September 1, 1981- } \\
\text { October } 10,2020\end{array}$ & Daily & $\begin{array}{l}\text { 1. Analysis of long-term ( } 39 \text { years) } \\
\text { dynamic of SST (averaged by area of } \\
\text { Avacha Bay). Comparison of heat } \\
\text { anomalies in summer } 2020 \text { with a cli- } \\
\text { mate normal } \\
\text { 2. Analysis of spatial SST distribution } \\
\text { in area of the entire Kamchatka in } \\
\text { summer } 2020 \text { and during ecological } \\
\text { disaster }\end{array}$ \\
\hline
\end{tabular}

a ground to space system of monitoring of coastal water areas [10].

The following significant water parameters, which are important for revealing negative impacts on coastal water areas, were registered [1, 2, 4, 10]: (i) spectral sea surface reflectivity in an optical range of electromagnetic waves, (ii) normalized radar cross section in the $\mathrm{C}$-band of radiowave spectra, (iii) concentration of chlorophyll $a$ in the subsurface seawater layer, (iv) SST, (v) velocity and direction of near surface wind, etc.

Specific attention in this work was paid to the concentration of chlorophyll $a$, which indicates the phytoplankton content in the surface layer of the water area [10], and SST. Table 1 shows the data sources, temporal intervals of monitoring, and key tasks, which are solved using these main parameters.

\section{RESEARCH RESULTS AND THEIR ANALYSIS}

The temporal series of daily spatial distributions of the concentration of chlorophyll $a$ (in relative units) in Avacha Bay, which are based on data of VIIRs multispectral instruments of NOAA missions (https:// www.star.nesdis.noaa.gov/) in various days of September-October 2020, is shown in Fig. 1.
The analysis of data shown in Fig. 1 allowed us to reveal a strong increase in the concentrations of chlorophyll $a$ (approximately 5-fold) as compared to previous days, which occurred on September 24, 2020 , spanning almost the entire area of the bay. The high concentration of chlorophyll $a$ in this area was observed during the next days. The highest concentration of chlorophyll $a$ (up to 7-8 times) was recorded on October 1, 2020 (Fig. 1).

To estimate the deviation from a normal level of the concentration during the environmental disaster, which led to mass death of hydrobionts, we analyzed the time series from MODIS spectral radiometers of AQUA and TERRA missions [11] from February 24, 2020, to October 31, 2020.

Preliminary processing and summarizing of more than 10000 archive space scenes resulted in distributions (from May to October) of average monthly concentrations of chlorophyll $a\left(\mathrm{mg} / \mathrm{m}^{3}\right)$ for the Avacha Bay from 2000 to 2020 (Fig. 2).

The analysis of data shown in this figure indicates that no such high average monthly concentrations of chlorophyll $a$ (as in the end of September and the beginning of October 2020) were observed in the Avacha Bay beginning from 2000. The average month 


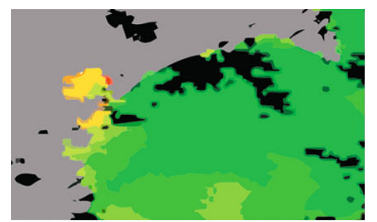

September 4, 2020

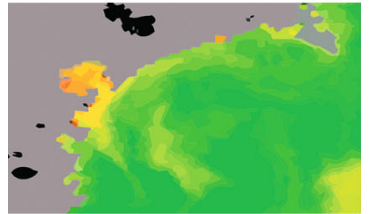

September 15, 2020

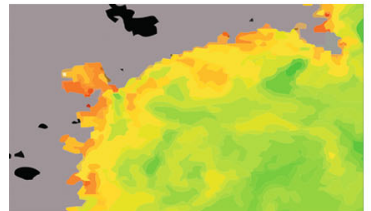

September 26, 2020

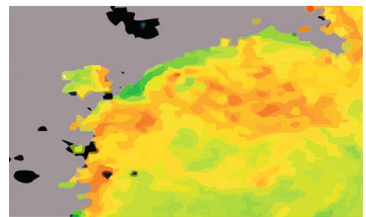

October 8, 2020

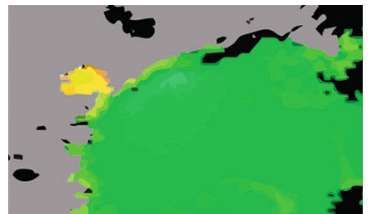

September 8, 2020

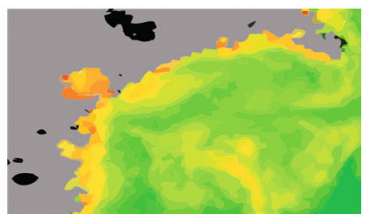

September 21, 2020

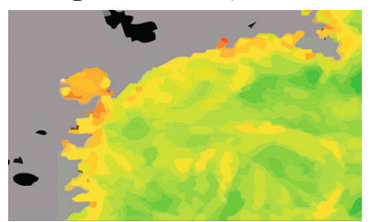

September 27, 2020

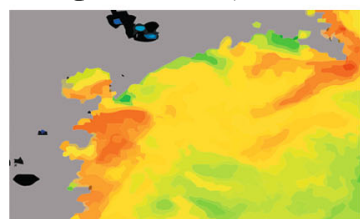

October 9, 2020

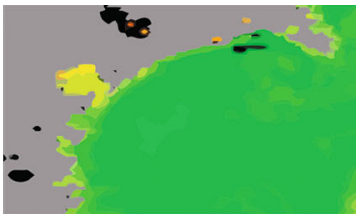

September 9, 2020

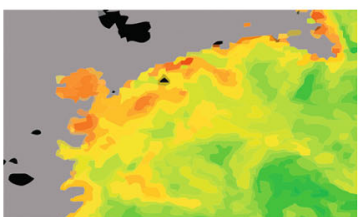

September 24, 2020

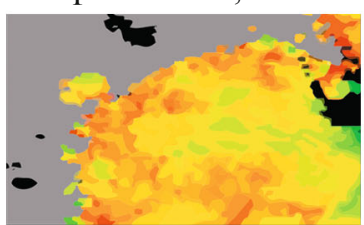

October 1,2020

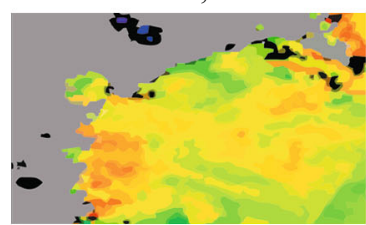

October 10, 2020

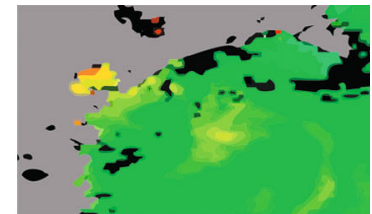

September 13, 2020

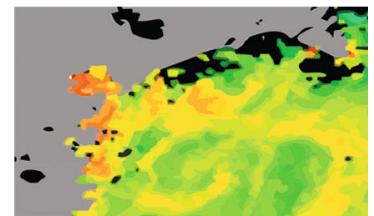

September 25, 2020

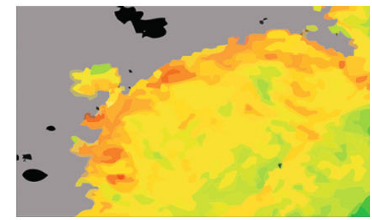

October 3, 2020

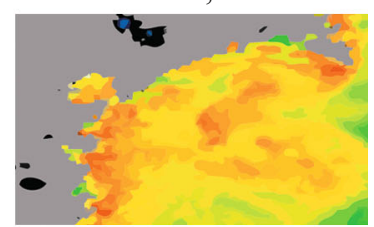

October 11, 2020

Concentration of chlorophyll $a$ (arbitrary units)

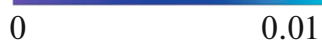

0.10

1.00

Fig. 1. Time series of daily spatial distributions of the concentrations of chlorophyll $a$ (relative units) in September-October 2020 measured in the Avacha Bay using VIIRS device of NOAA missions.

concentration of chlorophyll $a$ in October 2020 was $\sim 14.9 \mathrm{mg} / \mathrm{m}^{3}$ and the average value for $2000-2019$ (for October) was $\sim 3.8 \mathrm{mg} / \mathrm{m}^{3}$ at maximum of $\sim 9.3 \mathrm{mg} / \mathrm{m}^{3}$, which was observed in October 2017 (Fig. 2). Thus, the concentration of chlorophyll $a$ in October 2020 exceeded the climate normal value almost 4-fold and this parameter showed a historical maximum in the period from 2000 to 2020 .

These results indicate that the anomalously high concentration of chlorophyll $a$ (and hence, phytoplankton) were observed in the end of September-the beginning of October 2020. This is related to the intense harmful bloom of microalgae (so called red tide event [12]), which occurs in the Far East seas of Russia [4, 13] and other water areas [12]. The red tides saturate waters with toxins, which intoxicate some species of organisms of ecosystems [12, 13] leading to death of hydrobionts of the studied area.

A time series of average monthly maps of the concentration of chlorophyll $a$, which are based on satellite data, in coastal water areas of the entire Kamchatka Peninsula, was studied for estimation of spatial scales of an explosion of phytoplankton. Figure 3 shows the comparative spatial distributions of the con- centrations of this parameter for this region in September 2019 and 2020. The analysis of Figure 3 indicates that the concentrations of chlorophyll $a$ in September 2020 were significantly higher and observed in coastal water areas around the entire Kamchatka Peninsula. This also led to intense harmful bloom of microalgae (red tide [12, 13]), which was responsible for death of hydrobionts also in other underpopulated regions around Kamchatka Peninsula.

Possible reasons of the red tide-related anomalous increase in the concentrations of chlorophyll $a$ (growth of phytoplankton) were analyzed from SST in Avacha Bay and coastal areas of the entire Kamchatka. As known, the increase in SST leads to the increase in microalgae biomass, thus to the increase in the concentrations of chlorophyll $a$ (e.g., [14]).

The results of study of SST in the Kamchatka coastal areas are shown in Fig. 4. The dashed line shows the averaged (from 1981 to 2020) daily SSTs in Avacha Bay and the solid line shows the SSTs in various days of 2020, which are based on values of optimal interpolation temperature (NOAA OISST, version v2.1) from satellite and sea truth data and results of their interpolation [15]. 


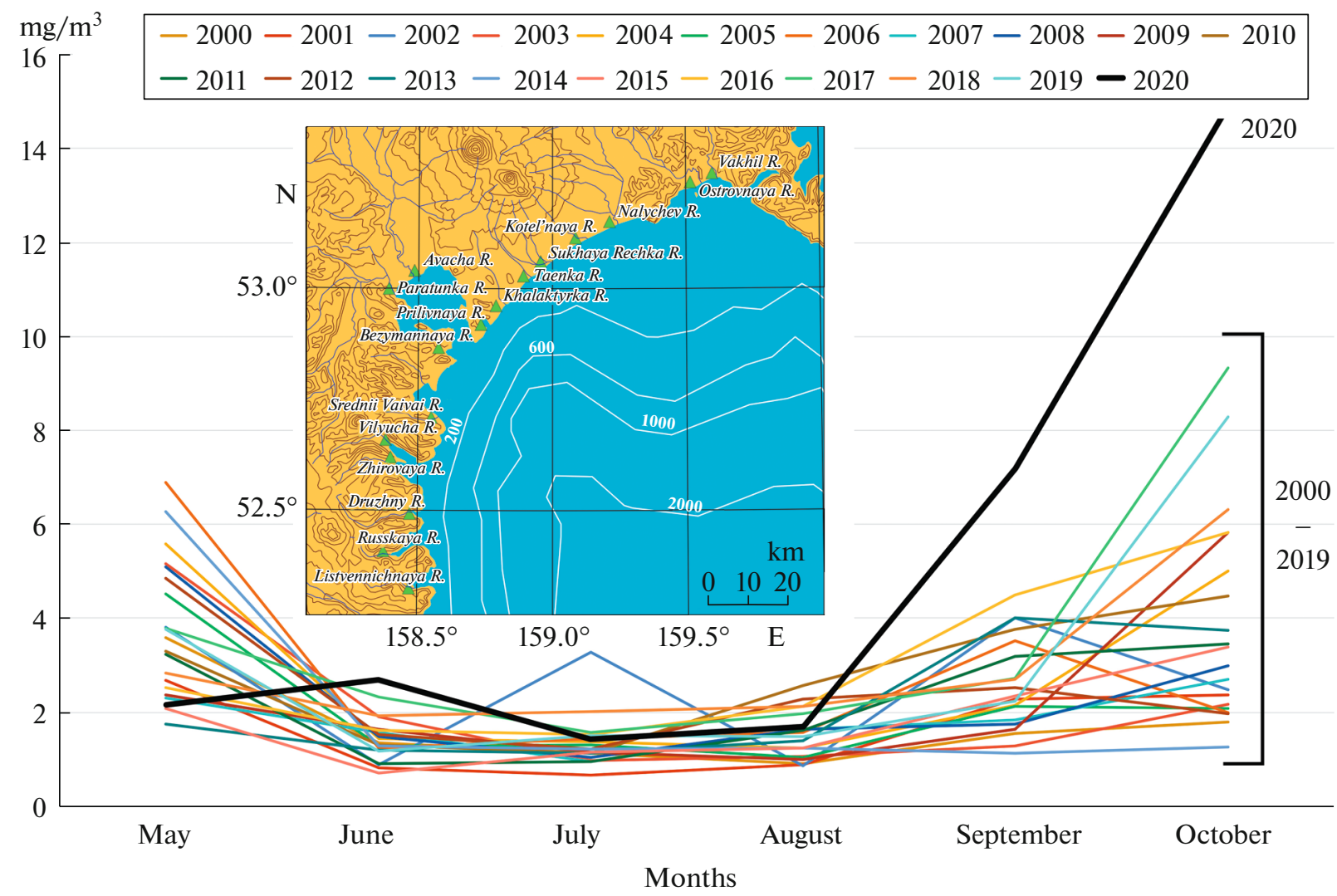

Fig. 2. Distributions of average monthly (from May to October) concentrations of chlorophyll $a\left(\mathrm{mg} / \mathrm{m}^{3}\right)$ in the Avacha Bay (inset) from 2000 to 2020.

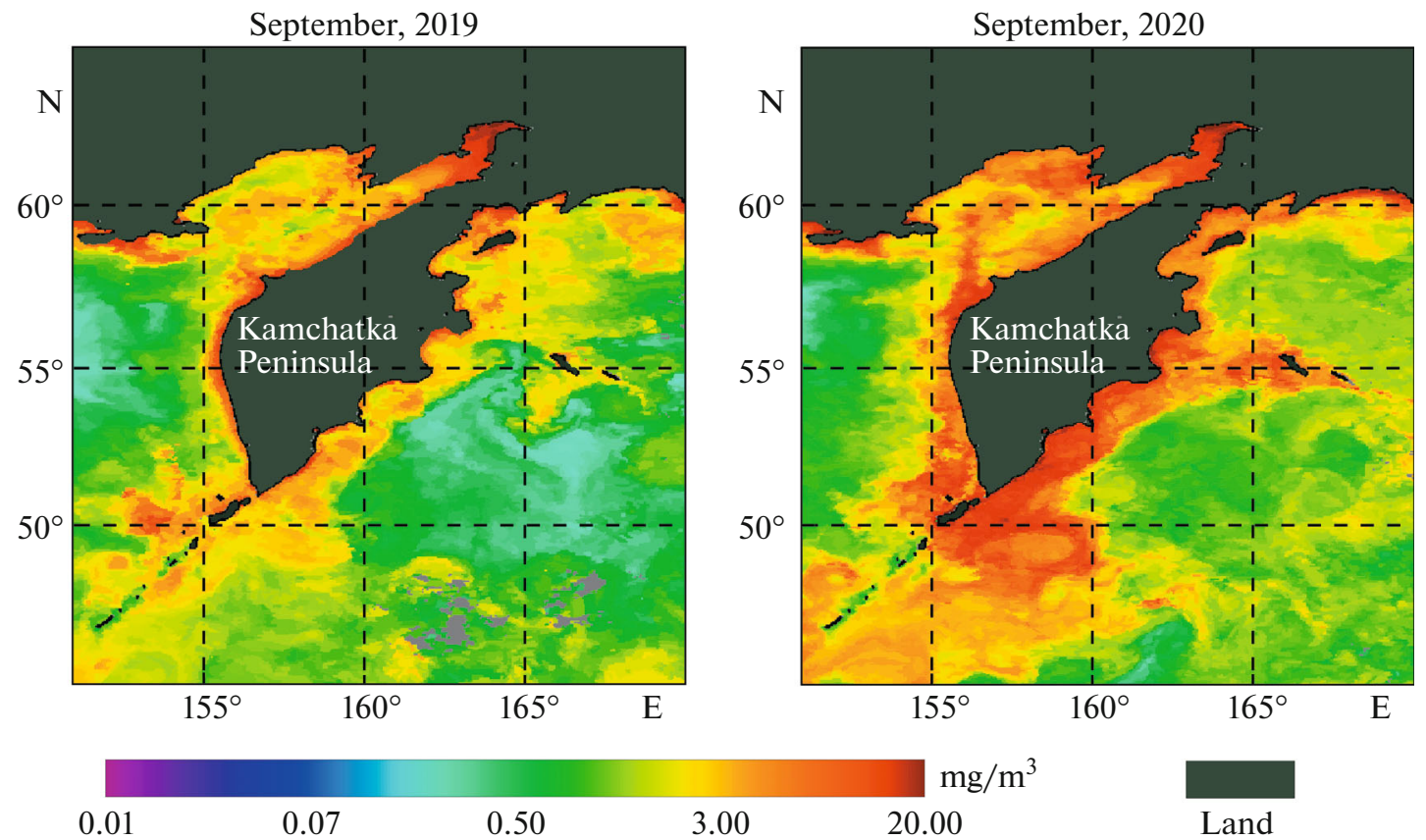

Fig. 3. Example of comparison of average monthly concentrations of chlorophyll $a\left(\mathrm{mg} / \mathrm{m}^{3}\right)$ in coastal water areas the Kamchatka Peninsula in September 2019 (left) and September 2020 (right). 


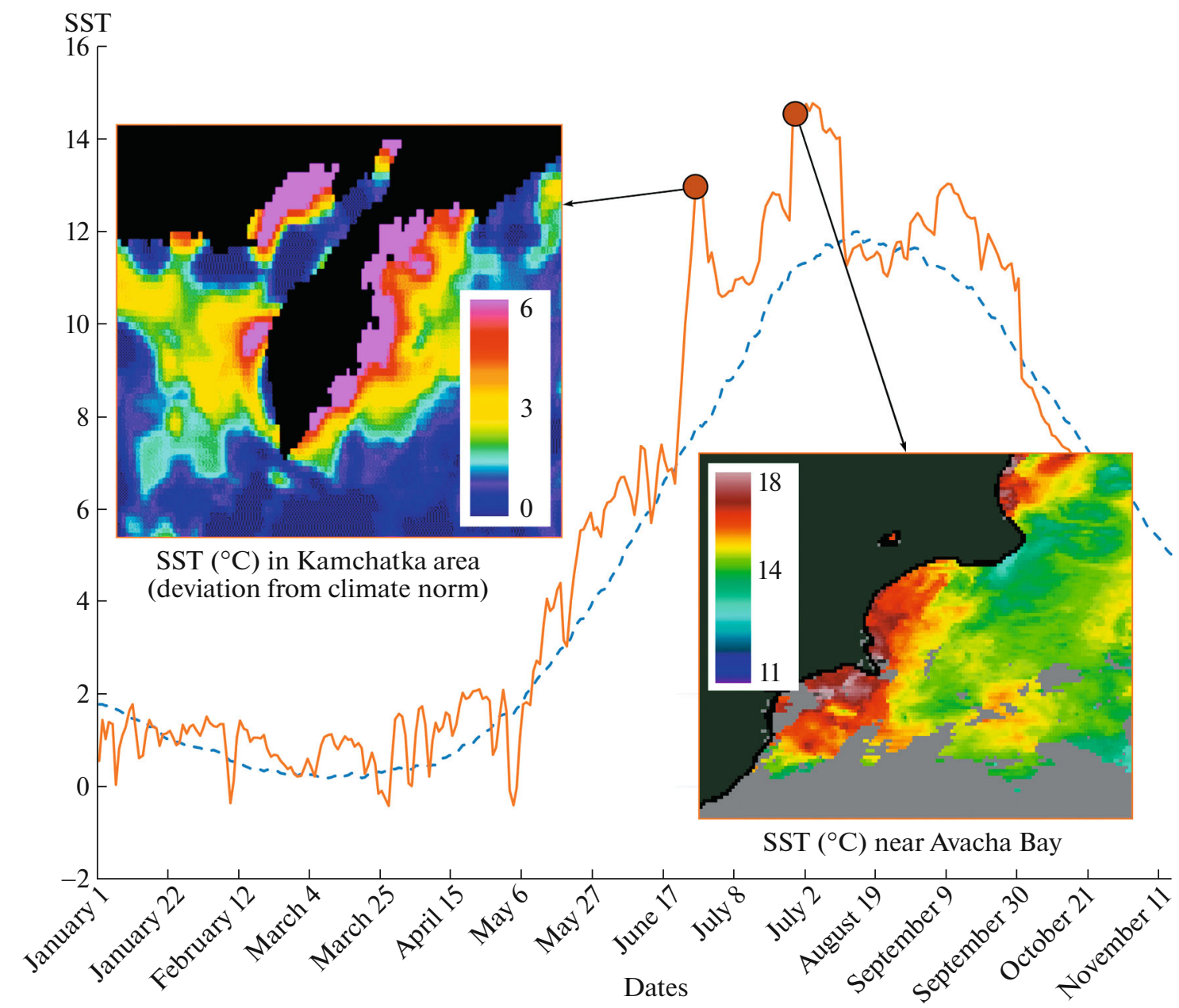

Fig. 4. Averaged daily SST values in Avacha Bay from 1981 to 2020 (dotted line) and SST in this bay in various days of 2020 (solid line) (NOAA/OISST data). Right inset: spatial SST distribution in bay on July 27, 2020 (AQUA/MODIS data). Left inset: deviation of SST on June 29, 2020 from climate norm in coastal water areas around Kamchatka (processing of NOAA/OISST data).

The right inset of Fig. 4 shows the spatial distribution of SST in Avacha Bay on July 27, 2020, which is a result of processing of data from MODIS instrument (AQUA mission). The left inset of Fig. 4 demonstrates the deviation of SST on June 29, 2020 from a climate norm in the coastal areas around the entire Kamchatka Peninsula (the result of processing of NOAA/OISST data).

It follows from the analysis of Fig. 4 that JuneSeptember 2020 exhibited anomalous SSTs (more than by $3-6^{\circ} \mathrm{C}$ ) in Avacha Bay as compared to the average multiannual values for these months. In particular, strong temperature anomalies with high value near the coast of Avacha Bay were registered according to the data of MODIS instrument (AQUA mission) on July 27, 2020 (shown in the right inset of Fig. 4). The positive SST anomalies, which exceed the climate normal by $3-6^{\circ} \mathrm{C}$, were also registered in vast areas along the entire Kamchatka Peninsula (see left inset in Fig. 4). This indicates that environmental disaster near the Kamchatka Peninsula, which led to mass death of hydrobionts in autumn 2020, has natural origin and is related to the increase in harmful bloom of algae (so called bear red tide), which was caused by significant positive temperature anomalies (up to $6^{\circ} \mathrm{C}$ ) in the studied water regions in summer of 2020.

\section{CONCLUSION}

Thus, the long-term series of satellite (more than 15000 scenes) and other data on the concentrations of chlorophyll a (from 2000 to 2020) and SST (from 1981 to 2020) are analyzed on the basis of results of space monitoring in Avacha Bay and coastal water regions of the entire Kamchatka Peninsula, where the environmental disaster related to mass death of hydrobionts occurred in autumn of 2020.

It was established using these data that the studied region in the end of September-the beginning of October 2020 was characterized by anomalous (relative to previous 20 years) increase in the concentrations of chlorophyll $a$ (5-8 times higher than back- 
ground values) indicating a significant change in biogenic regime.

The strong positive temperature anomalies (deviations from the climate norm up to $6^{\circ} \mathrm{C}$ ) in studied water areas in July-September 2020 facilitated harmful bloom of algae (red tide), which was responsible for death of hydrobionts in coastal zones of the Avacha Bay and the entire Kamchatka Peninsula.

Thus, the results of studies based on space data showed that natural factors were the reasons of extraordinary ecological situation, which caused mass death of hydrobionts in Avacha Bay and the coast of the entire Kamchatka Peninsula in autumn 2020. These factors are related to harmful bloom of algae (red tide), which occurred because of anomalous increase in water temperature relative to a climate normal.

\section{FUNDING}

This work was supported by the Ministry of Science and Higher Education of the Russian Federation (project no. 075-15-2020-776).

\section{OPEN ACCESS}

This article is distributed under the terms of the Creative Commons Attribution 4.0 International Public License (http://creativecommons.org/licenses/by/4.0/), which permits unrestricted use, distribution, and reproduction in any medium provided you give appropriate credit to the original author(s) and the source, provide a link to the Creative Commons license, and indicate if changes were made.

\section{REFERENCES}

1. V. G. Bondur, in Waste Water - Evaluation and Management (Croatia, 2011), pp. 155-180.

http://www.intechopen.com/articles/show/title/satellite-monitoring-and-mathematical-modelling-ofdeep-runoff-turbulent-jets-in-coastal-water-areas.

2. V. G. Bondur and E. V. Zubkov, Issled. Zemli Kosmosa, No. 4, 54-61 (2005).

3. S. P. Pugach, I. I. Pipko, N. E. Shakhova, E. A. Shirshin, I. V. Perminova, Ö. Gustafsson, V. G. Bondur, A. S. Ruban, and I. P. Semiletov, Ocean Sci. 14 (1),
87-103 (2018). https://doi.org/10.5194/os-14-87-2018

4. A. I. Aleksanin, V. A. Kachur, V. Kim, T. Yu. Orlova, A. N. Pavlov, P. A. Salyuk, I. V. Stonik, and O. G. Shevchenko, in Biological Safety of the Russian Far East Seas, Ed. by A. V. Adrianov (Dal'nauka, Vladivostok, 2014), pp. 325-353 [in Russian].

5. V. G. Bondur, Yu. V. Grebenyuk, and K. D. Sabinin, Izv., Atmos. Ocean. Phys. 45 (5), 598-608 (2009).

6. V. G. Bondur, Yu. V. Grebenjuk, and K. D. Sabinin, Oceanology (Engl. Transl.) 48 (5), 611-622 (2008).

7. V. Bondur and M. Tsidilina, in Proc. 31st Int. Symp. Remote Sensing of Environment. ISRSE 2005 (St. Petersburg, 2005), pp. 192-195.

8. V. G. Bondur, V. M. Zhurbas, and Yu. V. Grebenyuk, Oceanology (Engl. Transl.) 46 (6), 757-772 (2006).

9. V. G. Bondur, V. E. Vorobyev, V. V. Zamshin, A. N. Serebryany, A. A. Latushkin, M. E. Li, O. V. Martynov, A. P. Khurchak, and D. V. Grinchenko, Issled. Zemli Kosmosa, No. 6, 3-22 (2017). https://doi.org/10.7868/S020596141706001X

10. V. G. Bondur and V. V. Zamshin, in Proc. Sci.-Pract. Conf. "Research and Development-2016," Ed. by K. V. Anisimov et al. (San Diego, 2018), pp. 625-637. https://doi.org/10.1007/978-3-319-62870-7

11. NASA Goddard Space Flight Center, Ocean Ecology Laboratory, Ocean Biology Processing Group. Moderate-Resolution Imaging Spectroradiometer (MODIS) Aqua Chlorophyll Data, 2018 Reprocessing. NASA OB.DAAC, Greenbelt, MD, USA. https://doi.org/10.5067/AQUA/MODIS/L3M/CHL/2018

12. D. M. Anderson, in Red Tides: Biology, Environmental Science and Toxicology, Ed. by T. Okaichi, D. M. Anderson, and T. Nemoto (Elsevier, 1989), pp. 11-16.

13. T. Yu. Orlova, Vestn. Dal'nevost. Otd. Ross. Akad. Nauk, No. 1, 27-31 (2005).

14. I. N. Sukhanova and M. V. Flint, Oceanology 38 (4), 502-505 (1998).

15. R. W. Reynolds and V. F. Banzon, NOAA CDR Program: NOAA Optimum Interpolation 1/4 Degree Daily Sea Surface Temperature (OISST) Analysis, Vers. 2. NOAA National Centers for Environmental Information $(2008)$. https://doi.org/10.7289/V5SQ8XB5

Translated by I. Melekestseva 